\title{
Radionuclides in soils of Byers Peninsula, South Shetland Islands, Western Antarctica
}

A. Navas ${ }^{1}$, J. Soto ${ }^{2}$ \& J. López-Martínez ${ }^{3}$

${ }^{1}$ Estación Experimental de Aula Dei, CSIC, Apartado 202, Zaragoza, SPAIN. E-mail: anavas@eead.csic.es

${ }^{2}$ Dpt. Ciencias Médicas y Quirúrgicas. Universidad de Cantabria. Avda. Cardenal Herrera Oria s/n. 39011 Santander. SPAIN

${ }^{3}$ Dpt. Química Agrícola, Geología y Geoquímica, Facultad de Ciencias, Universidad Autónoma de Madrid, 28049 Madrid, SPAIN.

\section{Abstract}

As a part of a broader study of the surface formations in maritime Antarctica, a preliminary survey on the content of radionuclides has been carried out in soils of Byers Peninsula, located in the western end of Livingston Island, South Shetland Islands. Data on natural and artificial radionuclides are very scarce in Antarctica and the studied soil samples can be representative of the maritime Antarctic environment. Byers Peninsula has an extensive presence of permafrost and an active layer, being the studied soils Criosols and Cryic Leptosols. A series of soil cores between 13 and $40 \mathrm{~cm}$ depth have been collected in different lithological and altitudinal contexts. In the southwestern sector of the peninsula, soils have been sampled in seven different sites along a transect on different geomorphological units from an upper marine platform (88 $\mathrm{m}$ above sea level ) to a Holocene raised beach at an altitude of $24 \mathrm{~m}$ a.s.l. The parent materials are mainly Upper Jurassic-Lower Cretaceous marine sandstones and conglomerates and Lower Cretaceous volcanoclastic materials. Individual samples have been obtained from the cores according to 
textural and colour criteria and analysed for ${ }^{238} \mathrm{U},{ }^{226} \mathrm{Ra},{ }^{232} \mathrm{Th},{ }^{40} \mathrm{~K}$ and ${ }^{137} \mathrm{Cs}$ by gamma spectrometry. Radionuclides show variations in the depth profile as well as in the different morphoedaphic environments studied. Variability in some radionuclides seems to be related to mineralogy derived from parent materials as well as with cryogenic and soil processes affecting the depth distribution of the granulometric fractions and the organic matter.

Keywords: Radionuclides, depth distribution, soils, permafrost, cryogenic processes, Livingston Island, Antarctica.

\section{Introduction}

The knowledge of the distribution and mobilization of natural and artificial radionuclides in Antartica is very scarce. Sbrignadello et al. (1994) analyzed the distribution of ${ }^{210} \mathrm{~Pb}$ and ${ }^{137} \mathrm{Cs}$ in snow and in one soil sample at Terranova Bay. Roos et al. (1994) studied the deposition of ${ }^{210} \mathrm{~Pb}$ and other artificial radionuclides in vegetation and soils of the Antarctic Peninsula. Ye et al. (2000), studied the distribution of ${ }^{137}$ Cs in fauna, flora and surface soils in the Great Wall Station area (Fildes Peninsula, King George Island). Nevertheless, there is almost non existing information on the contents and distribution in soils of other natural radionuclides from the uranium and thorium decay series. These radionuclides occur in soil minerals or are adsorbed onto soil components and together with concentrations of ${ }^{40} \mathrm{~K}$, make the major contribution to the total terrestrial gamma-ray flux (Beck, 1972; Kiss et al., 1988). Therefore it is of interest to know their distribution and the factors involved in their mobilization, transfer and accumulation in this very special and fragile environment.

Another reason for the scarcity of studies on radionuclides in soils in Antarctica is in part due to the lack of ice and snow-free areas (less than $1 \%$ of the total surface). Therefore not much information exists on the distribution of natural and artificial gamma-ray emitting radionuclides 
in soils of the snow-free Antarctic areas. The objective of this study is to analyse the spatial and depth distribution of ${ }^{238} \mathrm{U},{ }^{226} \mathrm{Ra},{ }^{232} \mathrm{Th},{ }^{40} \mathrm{~K}$ and ${ }^{137} \mathrm{Cs}$ along a landscape sequence from a raised Pleistocene marine platform to a Holocene beach representative of the edaphic environments in maritime Antarctica. Because Byers Peninsula, with a surface of $60 \mathrm{~km}^{2}$, is the largest ice-free area in the South Shetland archipelago (Thomson \& López-Martínez, 1996), the study of contents of radionuclides can give valuable information on soil factors and processes that affect their spatial patterns, and about changes in environmental conditions in Antarctic ice-free areas.

\section{The study area}

Byers Peninsula is located in a maritime Antarctic environment, comprising part of the Antarctic Peninsula and the surrounding islands. The peninsula is located in the western end of Livingston Island, South Shetland Islands (aprox. $62^{\circ} 37^{\prime} \mathrm{S}, 61^{\circ} 6^{\prime} \mathrm{W}$ ), and has more favourable environmental conditions for soil development than other Antarctic regions (Fig. 1A). Mean annual precipitation in the region can exceed $500 \mathrm{~mm}$ and mean annual temperature is about $2^{\circ} \mathrm{C}$. In summer, precipitation is more than $100 \mathrm{~mm}$ and mean daily temperature is above $\mathrm{O}^{\circ} \mathrm{C}$ at sea level (Bañón, 1992; Rakusa-Suszczewski, 2002).

The rocks outcropping are mainly mudstones, sandstones, conglomerates and volcanic and volcaniclastic rocks (Upper Jurassic to Lower Cretaceous) intruded by different igneous bodies (e.g. Smellie et al., 1984; Crame et al., 1993). The last major deglaciation of the peninsula began around 5-4 Ka BP (Björck et al., 1991, 1996; Björck \& Zale, 1996). The geomorphology is characterized by the presence of extensive raised marine platforms and beaches, jointly with erosive and depositional features of glacial origin and a well developed drainage system, with many streams that are active during the summer and more than 60 lakes. All these features are well described in the geomorphological map (1:25000 scale) of the landforms and surface deposits by López-Martínez et al. (1995) and the Quaternary evolution of Byers Peninsula has 
been compiled by López-Martínez et al. (1996). The presence in certain areas of permafrost and of an active layer at $30 \mathrm{~cm}$ depth as well as the role of freeze-thaw, wetting and drying and other weathering mechanisms has been described by Hall $(1992,1993)$ and Serrano et al. (1996).

The soils have a very poorly developed profile and horizon differentiation is minimal. They are strongly affected by freeze-thaw cycles and the most significant effect is on the reduction of particle size, whereas permafrost and downward flow water determine leaching and translocation of soil components (Jie et al., 2000). Soils are very stony, they are Cryosols and Cryic Leptosols at the upper part of the raised platform. The soil characteristics have been described in detail by Navas et al. (2004). In general they have low organic matter (0.4-1.3 \%) and carbonate contents $\left(<0.7 \%\right.$, apart from $20 \%$ in deep layers of L-CS). Electrical conductivity is low $\left(0.2 \mathrm{dS} \mathrm{m}^{-1}\right)$ and $\mathrm{pH}$ ranges from 6.59 - 8.59 in soils of the Holocene beach and the upper platforms, respectively. Textures are loam on the raised platform and sandy loam on the beach and the soil bulk density range is $1.3-2.1 \mathrm{~g} \mathrm{~cm}^{-3}$. The vegetation developed on these soils is composed of mosses and lichens, mostly associated with stony soils, and grasses on the soils that are more finely textured on the Holocene beach.

\section{Materials and methods}

A transect of around 1,750 m following an altitudinal gradient was established from a raised Pleistocene marine platform towards a Holocene beach. Five cores (L-A, L-AS, L-BS, L-CS, and L-O) were collected along the slope of a glacially over-deepened lake basin between 88 and 70 $\mathrm{m}$ a.s.l., one core (C-O) was taken at $60 \mathrm{~m}$ a.s.l., and core P-O was at $24 \mathrm{~m}$ a.s.l. at a raised beach (Figs. 1B and 1C).

The soil profiles were sampled using an automatic core driller. Cores were extruded and sectioned following textural and colour criteria. The depth of sampling was $13 \mathrm{~cm}$ in sites L-A, L-O, C-O and P-O, but for L-AS, L-BS, L-CS, the depth reached $39 \mathrm{~cm}$. 
The depth interval soil samples were air dried and ground to pass a $2 \mathrm{~mm}$ sieve for soil analyses. Total weight of the samples and of finer and coarser fractions were recorded. Standard soil analysis techniques were used for $\mathrm{pH}$, carbonates and organic matter determinations. Granulometric analysis of the sand, silt and clay size fractions was performed using Coulter laser equipment. Samples were stirred and ultrasound used to facilitate particle dispersion. Coarse fractions were obtained by dry sieving.

Measurements of radionuclide activities in soil samples were undertaken by using a high resolution, low background, hyperpure coaxial gamma-ray detector (EG \& G ORTEC HPGe) coupled to an ORTEC amplifier and multichannel analyser. The detector has an efficiency of $20 \%$, a resolution of $1.86 \mathrm{keV}$ and is surrounded with shielding material to reduce the background counting rate. The detector was calibrated using standard samples in the same geometry as the measured samples.

Prior to analyses of the radionuclides, soil samples were packed in $100 \mathrm{~mL}$ PVC cylindrical containers that were kept sealed for 2 months. Gamma emission of ${ }^{238} \mathrm{U},{ }^{226} \mathrm{Ra},{ }^{232} \mathrm{Th}$, ${ }^{40} \mathrm{~K}$ and ${ }^{137} \mathrm{Cs}$ (in $\mathrm{Bq} \mathrm{kg}{ }^{-1}$ air-dry soil) was measured in the interval soil samples. Counting time was around $24 \mathrm{~h}$ and the analytical precision of the measurements is approximately $+/-5-10 \%$ for the natural radionuclides and $3 \%$ for ${ }^{137}$ Cs. Considering the appropriate corrections for laboratory background, the activity of ${ }^{226} \mathrm{Ra}$ was determined from the $352-\mathrm{keV}$ line of ${ }^{214} \mathrm{~Pb}$ (Van Cleef, 1994); ${ }^{40} \mathrm{~K}$ activity was calculated from the $1461 \mathrm{keV}$ photopeak; ${ }^{232} \mathrm{Th}$ is estimated from the $911-\mathrm{keV}$ photopeak of ${ }^{228} \mathrm{Ac},{ }^{238} \mathrm{U}$ was determined from the $63-\mathrm{keV}$ line of ${ }^{234} \mathrm{Th}$ and ${ }^{137}$ Cs was determined from the $662-\mathrm{keV}$ line. 


\section{Results}

\subsection{Radionuclides along the transect}

The concentrations of the radionuclides in $\mathrm{Bq} \mathrm{kg}{ }^{-1}$ ranged between 5 and 36 for ${ }^{238} \mathrm{U}, 3$ and 14 for ${ }^{226} \mathrm{Ra}, 4$ and 31 for ${ }^{232} \mathrm{Th}, 125$ and 810 for ${ }^{40} \mathrm{~K}$ and from 0.5 to 4 for ${ }^{137} \mathrm{Cs}$. Table 1 presents a summary statistics of the radionuclides. Mean activity values fall within the normal ranges in nature, although activities are in general lower than values found in other environments (e.g. de Jong et al., 1994; Litaor, 1995; Navas et al., 2002a). ${ }^{40} \mathrm{~K}$ and ${ }^{137} \mathrm{Cs}$ show the highest variation with coefficients of 72 and $87 \%$ respectively whereas ${ }^{226} \mathrm{Ra}$ is the less variable.

As can be seen in Table 2 the natural gamma radionuclides are highly correlated indicating a common source from the parent materials (Fairbridge, 1972). The lower coefficient between ${ }^{238} \mathrm{U}$ and ${ }^{226} \mathrm{Ra}$ may be due to soil processes that affect differently the mobility of the two members of the uranium decay series. As expected, the natural radionuclides do not correlate with the artificially emitted ${ }^{137}$ Cs.

Correlations were established among the radionuclides with the main soil properties such as grain size, organic matter and carbon contents, electrical conductivity, carbonates and $\mathrm{pH}$, but few were significant. In these Antarctic soils, only ${ }^{137} \mathrm{Cs}$ was positively correlated with sand $(\mathrm{r}=$ 0.736) and negatively with silt $(r=-0.746)$, this could be due to the pattern distribution of soil particles along the soil profile, because the higher ${ }^{137} \mathrm{Cs}$ activities are at the soil surface that in turn presents higher contents of coarse particles. Increasing contents of organic matter and carbon were related to higher ${ }^{238} \mathrm{U},{ }^{232} \mathrm{Th}$ and ${ }^{40} \mathrm{~K}$ activities as indicated by the respective positive and significant correlation coefficients $(r=0.651, r=0.645, r=0.680)$.

The pattern distribution of the radionuclides along the transect from the platform to the raised beach can be seen in Figure 2 where the mean activities at the sampling sites are represented. For the natural radionuclides, the highest activities are found at the footslope of the glacially overdeepened basin (L-A) which is located at the beginning of the transect at an altitude of $70 \mathrm{~m}$ 
a.s.l. (Fig. 1C) Activities decrease towards the headwaters of this small lake basin, thus at the midslope the lowest activities are found and at the crest (88 $\mathrm{m}$ a.s.l.) all the natural radionuclides have values slightly lower than at the remaining sites along the transect, apart from ${ }^{238} \mathrm{U}$ that remains quite constant until the beach site. Therefore all the natural radionuclides exhibit a notably parallel distribution along the studied transect.

The footslope sites (L-AS, L-A) have the highest average concentrations of ${ }^{238} \mathrm{U},{ }^{226} \mathrm{Ra}$ and ${ }^{232} \mathrm{Th}$, around 26, 12 and $25 \mathrm{~Bq} \mathrm{~kg}^{-1}$, respectively. The concentrations of ${ }^{40} \mathrm{~K}$ are much higher than of the other radionuclides. The lower values for ${ }^{40} \mathrm{~K}\left(125-215 \mathrm{~Bq} \mathrm{~kg}^{-1}\right)$ are found at the crest and the midslope sites of the basin. On the beach and at the $60 \mathrm{~m}$ a.s.l platform site values range between 225 and $315 \mathrm{~Bq} \mathrm{~kg}^{-1}$. The highest concentrations occur also at the footslope where ${ }^{40} \mathrm{~K}$ activities reach $810 \mathrm{~Bq} \mathrm{~kg}{ }^{-1}$.

The distribution of ${ }^{137}$ Cs also follows this pattern although activities do not vary as much as that of the natural radionuclides. The lowest ${ }^{137} \mathrm{Cs}$ concentrations are registered in sites of the small lake basin, apart from that at its lower end (footslope L-A) where ${ }^{137} \mathrm{Cs}$ is highest (4 Bq $\mathrm{kg}^{-1}$ ) at the upper layers. The values at the soil surface of the remaining sites along the transect are quite similar (around $3.5 \mathrm{~Bq} \mathrm{~kg}^{-1}$ ) and almost disappear below $6 \mathrm{~cm}$ depth. The ${ }^{137} \mathrm{Cs}$ contents are lower than those found by Sbrignadello et al. (1994) in soil samples collected at Priestly Nevé plateau (inland Terranova Bay); the reason could be the difference in altitude as the plateau is at $1,998 \mathrm{~m}$ a.s.l., therefore the total precipitation and associated fallout of ${ }^{137} \mathrm{Cs}$ could have been higher. Another reason is that on ice free areas geomorphic and soil processes are more active and therefore some ${ }^{137} \mathrm{Cs}$ loss in association with that of the finer soil particles may occur.

In maritime Antarctica, cryogenic processes are very relevant and are responsible for the abundant patterned and classified soils present in Byers Peninsula (Serrano \& López-Martínez, 1998). Therefore it is of interest to analyse the distribution of coarse and fine fractions in the studied soils in order to examine their relationships with the radionuclide distributions. Figure 3 
depicts the average values of the granulometric fractions along the transect. In general there is a decrease in the percentages of all the three coarse fractions registered at the Holocene raised beach and from the footslope to the crest of the basin, apart from the coarsest fraction $(<12.5$ $\mathrm{mm}$ ) whose largest content is found at the crest of the basin on the platform (L-CS). In relation with the finer materials, silt increases gradually from the footslope to the crest of the small basin and then decreases gradually towards the beach. The opposite is found for sand. Clay is higher at the footslope of the basin and decreases smoothly towards the crest and then percentages remain quite constant towards the beach.

The concentrations of the natural radionuclides along the transect show a distribution highly parallel with that of the finer fractions, especially with the clay distribution at all the transect positions. This is observed also for ${ }^{40} \mathrm{~K}$ and ${ }^{232} \mathrm{Th}$ apart from the site at the Holocene beach, where they increase slightly. Similarly as expected, the distribution of ${ }^{137}$ Cs shows a close pattern to that of clay. Decreasing concentrations of the artificial radionuclide occur from the footslope to the crest of the small basin, and for the rest of the transect the values increase slightly and remain quite homogeneous until the Holocene beach.

\subsection{Depth distribution of the radionuclides}

Research on the soil factors that influence radionuclide transfer and how pedogenesis affects their depth distributions along soil profiles has been carried out by Navas et al. (2002b) in a very different environment such as the Mediterranean Spanish mountain. Similarly, to assess if soil and geomorphic processes affect the radionuclide activities, their depth profile distribution has been examined in detail at the three sites located along the slope of the lake basin where sampling depth reached $39 \mathrm{~cm}$. The remaining sites will allow an interpretation of features just on the upper soil layer (13 cm depth). 
The depth profiles of the natural and artificial radionuclides show different patterns along the different slope positions within the lake basin (Fig. 4). In spite of the very low concentration of ${ }^{137} \mathrm{Cs}$, less than $2 \mathrm{~Bq} \mathrm{~kg}^{-1}$ in the upper layers, the radionuclide presents a slight exponential decay with depth in all sites, although it is more marked at the crest of the lake basin. Nevertheless, below the upper soil layers concentrations are almost negligible $\left(0.5 \mathrm{~Bq} \mathrm{~kg}{ }^{-1}\right)$. At the midslope and footslope positions, ${ }^{137} \mathrm{Cs}$ is slightly more depleted at the soil surface than at the crest (L-CS, L-O). Although differences among the sites are minimal ( $\left.1 \mathrm{~Bq} \mathrm{~kg}^{-1}\right)$, they could be due to small soil losses as the mobility of the radioisotope is associated with that of soil. Soil movement may be more intense in the lower sections of the basin where there is a more abundant water circulation (Cuchí et al., 2004).

Figure 5 shows the depth distribution of sand, silt and clay along the transect, the fractions of interest in relation with the distribution of the radioisotope. The crest (L-CS, L-O) has more sand whereas clay content increases gradually from the crest to the midslope (L-BS) and footslope (L-AS) positions. Therefore, topography and water circulation are the factors that determine the soil movement registered in the basin. By comparing with the concentrations of ${ }^{137} \mathrm{Cs}$ in the rest of the transect, the lower values found along the slope of the basin may indicate soil loss. This is also in agreement with the grain size distribution and will support a more intense dynamic of soil movement in the basin by comparing with the rest of the transect. However, small differences in activities among the sites, as well as on the grain size contents, do not permit an extraction of more reliable information and further research is needed for better assessment on the pattern of soil movement in Byers Peninsula.

Concerning the natural radionuclides, the concentration of ${ }^{238} \mathrm{U}$ decreases with depth at the crest and midslope sites of the basin. ${ }^{238} \mathrm{U}$ varies between $20-17 \mathrm{~Bq} \mathrm{~kg}^{-1}$ at the upper layers and less than $8 \mathrm{~Bq} \mathrm{~kg}$ in lower layers. Nevertheless, at the footslope the contrary is observed, depletion occurs in the upper layer (6 Bq kg ${ }^{-1}$ ) and a significant enrichment is registered in lower layers where concentrations reach $36 \mathrm{~Bq} \mathrm{~kg}$. The depth distribution of ${ }^{226} \mathrm{Ra}$ and ${ }^{232} \mathrm{Th}$ follows 
a similar pattern, although not as marked as ${ }^{238} \mathrm{U}$ because concentrations are more homogoneous, especially that of ${ }^{226} \mathrm{Ra}$. The concentrations of these radionuclides are lower at the crest and

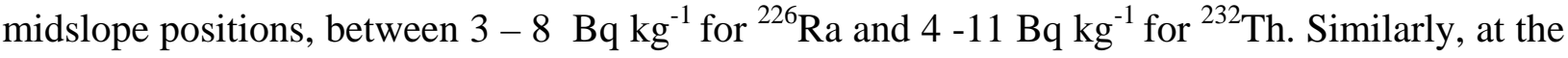
footslope an enrichment in ${ }^{226} \mathrm{Ra}$ and ${ }^{232} \mathrm{Th}$ is observed in lower soil layers as their concentrations are almost double those of the upper layers. There is little variation in the depth distribution of ${ }^{40} \mathrm{~K}$ at all sites, apart from the footslope sites in the lake basin. ${ }^{40} \mathrm{~K}$ concentrations increase in the lower soil layers, where values double those of the upper layers.

The variations in the depth distribution of the natural radionuclides are paralleled by changes in some soil properties. Thus at the crest of the basin the decrease with depth of ${ }^{238} \mathrm{U}$, and to a lesser extent of ${ }^{226} \mathrm{Ra}$ and ${ }^{232} \mathrm{Th}$, is accompanied by a decrease of the organic matter content from 1.27 to $0.54 \%$ at lower layers. Whereas $\mathrm{pH}$ increases from 7.9 to 8.6 due to a large variation in the content of carbonates that increases from almost negligible in the upper layers to $20 \%$ in the lower layers. In soil profiles of Mediterranean mountain areas, carbonate content was related to restricted mobility of natural radionuclides (Navas et al., 2002a). Nevertheless at the footslope all the natural radionuclides increased significantly with depth. In this soil profile there are not significant variations with depth in $\mathrm{pH}$ and carbonates, therefore these soil properties do not affect the radionuclide distribution at this site.

The highest clay content is found at the footslope of the basin and this appears to be the reason for the highest radioactivities found at this site. As is widely known in the literature, (e.g. VandenBygaart and Protz, 1995) the radionuclides are associated with clay minerals or they are fixed within the lattice structure. This fact is confirmed by the depth distribution of clays whose increase from 17 to $31 \%$ in the lower layers parallels a significant enrichment of all the natural radionuclides with depth. Besides, an increase in the organic matter content in the lower layers may also be related to the increase of the clay percentage. On the other hand, the analysis of the elemental composition in this soil profile revealed that K significantly increases with depth, from 6500 to $15000 \mathrm{mg} \mathrm{kg}^{-1}$, which is directly related with the ${ }^{40} \mathrm{~K}$ increase. Furthermore, at this 
footslope site the mineralogy in the lower layers had the highest percentage (52\%) of sheet silicates, mainly chlorite and minor contents of illite (Navas et al., 2004).

The interpretation of these results indicates that among the cryogenic processes, the cycles of freeze - thaw are responsible of the particle size reduction that it is observed from the crest to the footslope and that is favoured by the presence of abundant water during midsummer. Besides, soil movement downslope determines the accumulation of finer fractions at footslope sites. This in turn facilitates the accumulation of minerals (especially sheet silicates) that may contain the natural radionuclides. When analysing the distribution of soil properties and radionuclides along the soil profile, other processes that may play a role in their mobility and distribution become important. Thus at the footslope sites, clays and organic matter are leached out of the upper part of the soil and they accumulate in the lower layers. This happens at the footslope site because the downward flow of water is more intense in this lower topographic position. Besides, at this site, it is expected to have a larger range of the active layer than at the steeper crest and midslope sites, hence water movement down the profile should be more intense. On the upper slope sites decreasing contents of natural radionuclides with depth may be caused by lower water availability that limits the transport of clay minerals down the profile. Therefore, the distribution of natural radionuclides is mainly associated with that of minerals of parent materials through geomorphic and soil processes that trigger the enrichment of the clay fraction.

In contrast to what has been described in some Mediterranean environments (Navas et al., 2002b), where ${ }^{238} \mathrm{U}$ is highly mobile and is leached from the soil surface, in the soils at the upper slope of Byers Peninsula, ${ }^{238} \mathrm{U}$ accumulates in the upper layers. According to Harmsen and de Haan (1980), $\mathrm{U}$ and Th form hydrated cations $\left(\mathrm{UO}_{2}{ }^{2+}, \mathrm{Th}^{4+}\right)$ that are easily mobilized over a broad range of soil $\mathrm{pH}$. Nevertheless, in the maritime Antartica environment it seems that mobilization of radionuclides from the $U$ and Th decay series is very limited. The transference of the radionuclides down the profile seems to be restricted by the short time in which water 
circulates down the soil profile. Therefore, it appears that the contents of the natural radionuclides in soils, is mainly related to the mineral composition of the parent materials and that their accumulation in lower soil layers occurs by the accumulation of clay minerals that contain the radionuclides. Hence, this is not due to the proper leaching of the radionuclides, but of the clay minerals to which the natural radionuclides are associated and the leaching occurs during the short periods of water circulation.

\section{Conclusions}

In the soils of Byers Peninsula, the contents of the natural radionuclides differ among the soils along the morphoedaphic environments in the studied transect. The spatial variability and the soil profiles are in close relation with the mineralogy of parent materials.

In this environment, geomorphological (cryogenic) and downslope soil movement are the predominant processes involved in the transport of soil particles and affecting the pattern distribution of the natural radionuclides. Intensity of the leaching of soil particles seems to be related to that of water circulation and the fluctuations of the active layer.

The concentrations of the artificially emitted ${ }^{137} \mathrm{Cs}$ were very low, and especially in the lake basin its depleted levels reflected the soil movement downslope in comparison with higher contents at more level sites along the transect. Nevertheless, further research is needed to overcome the restrictions of the very low concentrations that limit the interpretation of the processes. 


\section{Acknowledgements}

This work is a contribution to the Spanish R \& D National Plan research projects REN20010643 and REN2002-02702/GLO, that provided the financial support. We thank the cooperation for sampling during the field work of the members of the project REN2000-0435.

\section{References}

Bañón, M., 1992. El clima en las Shetland del Sur y el norte de la Península Antártica. Caso de la BAE Juan Carlos I. La Meteorología, II, (7-8), 38-45.

Beck, H.L., 1972. The physics of environmental gamma radiation fields. In: Proceedings 2nd International Symposium on Natural Radiation Environment, Houston, TX, NATL, Springfield, VA. pp.101-301.

Björck, S., Hakansson, H., Zale, R., Karlen, W., Jönsson, B.L., 1991. A late Holocene lake sediment sequence from Livingston Island, South Shetland Islands, with palaeoclimatic implications. Ant. Sc. 3, 61-72.

Björck, S., Hjort, C., Ingólfsson, O., Zale, R., Ising, J., 1996. Holocene deglaciation chronology from lake sediments. In: López-Martínez, J., Thomson, M.R.A., Thomson, J.W. (Eds.), Geomorphological map of Byers Peninsula, Livingston Island. BAS Geomap Series 5-A. British Ant Surv, Cambridge, pp. 49-51.

Björck, S., Zale, R., 1996. Late Holocene tephrochronology and palaeoclimate, based on lake sediment studies. In: López-Martínez, J., Thomson, M.R.A., Thomson, J.W. (Eds.), Geomorphological map of Byers Peninsula, Livingston Island. BAS Geomap Series 5-A. British Ant Surv, Cambridge, pp. 43-48. 
de Jong, E., Acton, D.F., Kozak, L.M.,1994. Naturally occurring gamma-emitting isotopes, radon release and properties of parent materials of Saskatchewan soils. Can. J. Soil Sci. 74, 47-53.

Crame, J.A., Pirrie, D., Crampton, J.S., Duane, A.M., 1993. Stratigraphy and regional significance of the Upper Jurassic-Lower Cretaceous Byers Group, Livingston Island, Antarctica. J. Geol. Soc. London, 150, 1075-1087.

Cuchí, J.A., Durán, J.J., Alfaro, P., Serrano, E. y López-Martínez, J., 2004. Discriminación mediante parámetros fisicoquímicos in situ de diferentes tipos de agua presentes en un área con permafrost (península Byers, isla Livingston, Antártida occidental). Bol. R. Soc. Esp. Hist. Nat. (Secc. Geol.), 99(1-4), 75-82

Fairbridge, R.W., 1972. The encyclopedia of geochemistry and environmental sciences. Van Nostrand Reinhold Co., New York, Vol. 4A. pp. 1215-1228.

Hall, K.J., 1992. Mechanical weathering on Livingston Island, South Shetland Islands, Antarctica. In: Yoshida, Y., Kaminuma, K., Shiraishi, K. (Eds.), Recent Prog. Antarct. Earth Sci. Terra, Tokyo, pp. 756-762.

Hall, K.J., 1993. Enhanced bedrock weathering in association with late-lying snowpatches: evidence from Livingston Island, Antarctica. Earth Surf. Proc. Land 18, 121-129

Harmsen, K., de Haan, F.A.M., 1980. Occurrence and behavior of uranium and thorium in soil and water. Neth.J. Agric.Sci., 28, 40-62.

Jie, Ch., Zitong, G., Blume, H.P., 2000. Soils of Fildes Peninsula, Kin George Island, the maritime Antarctic: Part 1, Formation processes an pedogenetic particularities. Chinese J. Polar Sci. 11(1), 25-38.

Kiss, J.J., de Jong, E., Bettany, J.R., 1988. The distribution of natural radionuclides in native soils of southern Saskatchewan, Canada, J. Environ. Qual. 17, 437-445. 
Litaor, M.I., 1995. Uranium isotopes distribution in soils at the Rocky Flats Plant, Colorado, J. Environ. Qual. 24, 314-323.

López-Martínez, J., Martínez de Pisón, E., Serrano, E., Arche, A., 1995. Geomorphological map of Byers Peninsula, Livingston Island, E. 1:25 000. BAS Geomap Series 5-A. British Ant Surv, Cambridge.

López-Martínez, J., Thomson, M.R.A., Thomson, J.W., (Eds.). 1996. Geomorphological map of Byers Peninsula, Livingston Island. BAS Geomap Series 5-A. British Ant Surv, Cambridge, pp. 65.

Navas, A., Soto, J., Machín, J., 2002a. ${ }^{238} \mathrm{U},{ }^{226} \mathrm{Ra},{ }^{210} \mathrm{~Pb},{ }^{232} \mathrm{Th}$ and ${ }^{40} \mathrm{~K}$ activities in soil profiles of the Flysch sector (Central Spanish Pyrenees). Appl. Radiat. Isotopes 57 (4), 579-589.

Navas, A., Soto, J., Machín, J., 2002b. Edaphic and physiographic factors affecting natural gamma emitting radionuclide distribution in soils of the Arnás basin (Central Spanish Pyrenees). European J. Soil Sci. 53, 629-638.

Navas et al., 2005. First study on soil characteristics along a transect on raised marine surfaces in Byers Peninsula, Livingston Island, South Shetland Islands In: Fütterer, D.K. (ed) Antarctic Contributions to Global Earth Science, Proceedings ISAES -IX (in press).

Rakusa-Suszczewski, S., 2002. King George Island, Maritime Antarctica. In: Beyer, L., Bölter, M. (Eds.), Geoecology of Antarctic Ice Free Coastal Landscapes. Springer, Berlin, pp. 23-40. Roos, P., Holm, E., Persson, R.B.R., Aarkrog, A., Nielsen, S.P., 1994. Deposition of ${ }^{210} \mathrm{~Pb}$, ${ }^{137} \mathrm{Cs},{ }^{239+}{ }^{240} \mathrm{Pu},{ }^{238} \mathrm{Pu}$, and ${ }^{241} \mathrm{Am}$ in the Antarctic peninsula area. J. Environ. Radioactiv. 24, 235-251.

Sbrignadello, G., Degetto, S., Battiston, G.A., Gerbasi, R., 1994. Distribution of ${ }^{210} \mathrm{~Pb}$ and ${ }^{137} \mathrm{Cs}$ in snow and soil samples from Antarctica. Intern. J. Environ. Anal. Chem. 55, 235-242.

Serrano, E., López-Martínez, J., 1998. Caracterización y distribución de las formas y los procesos periglaciares en las islas Sthetland del sur (Antártida). In: Gomez, A., Salvador, F., 
Schulte, L., García, A. (Eds.), Procesos biofísicos actuales en medios fríos. Universidad de Barcelona, Barcelona, pp. 181-204.

Serrano, E., Martínez de Pisón, E., López-Martínez, J., 1996. Periglacial and nival landforms and deposits. In: López-Martínez, J., Thomson, M.R.A., Thomson, J.W. (Eds.), Geomorphological map of Byers Peninsula, Livingston Island BAS Geomap Series 5-A. British Ant Surv, Cambridge, pp. 15-19.

Smellie, J.L., Pankhurst, R.J., Thomson, M.R.A., Davies, R.E.S., 1984. The geology of the South Shetland Islands: VI. Stratigraphy, geochemistry and evolution. British Ant. Surv. Sc Reports 87, pp.85.

Thomson, M.R.A., López-Martínez, J., 1996. Introduction to the Geology and Geomorphology of Byers Peninsula. In: López-Martínez, J., Thomson, M.R.A., Thomson, J.W. (Eds.), Geomorphological map of Byers Peninsula, Livingston Island BAS Geomap Series 5-A. British Ant Surv, Cambridge, pp. 1-4.

Van Cleef, D.J., 1994. Determination of ${ }^{226} \mathrm{Ra}$ in soil using ${ }^{214} \mathrm{~Pb}$ and ${ }^{214} \mathrm{Bi}$ inmediately after sampling. Health Phys. 67, 288-289.

VandenBygaart, A.J., Protz, R., 1995. Gamma radioactivity on a chronosequence, Pinery Provincial Park, Ontario. Can. J. Soil Sci. 75, 73-84.

Ye, Z., Tianjie, L., Cuihua, X., 2000. The ${ }^{137}$ Cs activity and its geographical significance in terrestrial ecosystem of Great Wall Station, Antarctica. Chinese J. Polar Sci. 11(1), 39-42. 
FIGURE AND TABLE CAPTIONS

Fig. 1. Location of Byers Peninsula (A). Simplified geomorphological sketch map of Byers Peninsula and sampling sites (B). Location of samples along a profile on the slope of the lake $\operatorname{basin}(\mathrm{C})$.

Fig.2. Pattern distribution of the radionuclides along the studied transect.

Fig. 3. Average values of the granulometric fractions along the transect. For locations see Fig.1.

Fig. 4. Depth profile of radionuclides at three sampling sites located along the slope of the lake basin. For location see Fig. 1.

Fig. 5. Depth distribution of sand, silt and clay along the transect. For locations see Fig. 1.

\section{TABLES}

Table 1 . Summary statistics of the radionuclides.

Table 2. Pearson correlation coefficients among the radionuclides. 
Table 1. Summary statistics of the radionuclides.

\section{Count}

Average

Standard deviation

Minimum

Maximum

\begin{tabular}{rrrrr}
${ }^{238} \mathbf{U}$ & ${ }^{226} \mathbf{R a}$ & ${ }^{{ }^{232}} \mathbf{T h}$ & ${ }^{{ }^{40} \mathbf{K}}$ & ${ }^{\mathbf{1 3 7}} \mathbf{C s}$ \\
\hline 21 & 21 & 21 & 21 & 21 \\
16.2 & 8.0 & 13.1 & 317.1 & 1.2 \\
9.6 & 3.7 & 8.1 & 227.0 & 1.1 \\
5.0 & 3.0 & 4.0 & 125.0 & 0.5 \\
36.0 & 14.0 & 31.0 & 810.0 & 4.0
\end{tabular}


Table 2. Pearson correlation coefficients among the radionuclides.

\begin{tabular}{lrrrrr}
${ }^{238} \mathrm{U}$ & ${ }^{238} \mathrm{U}$ & ${ }^{226} \mathrm{Ra}$ & ${ }^{232} \mathrm{Th}$ & ${ }^{40} \mathrm{~K}$ & ${ }^{137} \mathrm{Cs}$ \\
\cline { 2 - 6 }${ }^{226} \mathrm{Ra}$ & $\mathbf{1}$ & & & & \\
${ }^{232} \mathrm{Th}$ & $\mathbf{0 . 6 9 4}$ & $\mathbf{1}$ & & & \\
${ }^{40} \mathrm{~K}$ & $\mathbf{0 . 8 6 5}$ & $\mathbf{0 . 8 5 3}$ & $\mathbf{1}$ & & \\
${ }^{137} \mathrm{Cs}$ & $\mathbf{0 . 8 3 6}$ & $\mathbf{0 . 8 1 6}$ & $\mathbf{0 . 9 6 1}$ & $\mathbf{1}$ & \\
& -0.016 & 0.080 & 0.121 & 0.075 & $\mathbf{1}$
\end{tabular}




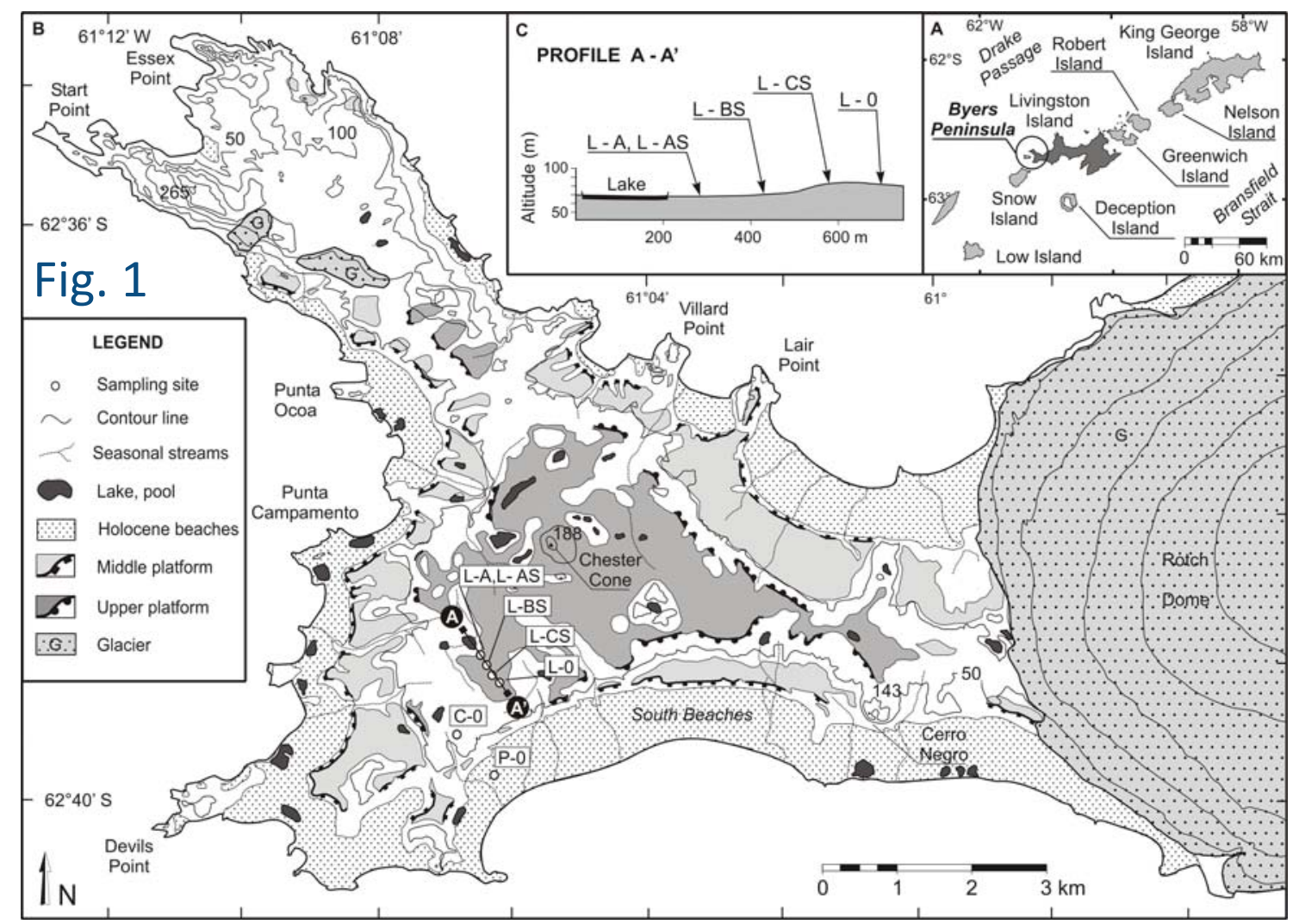


Fig. 2

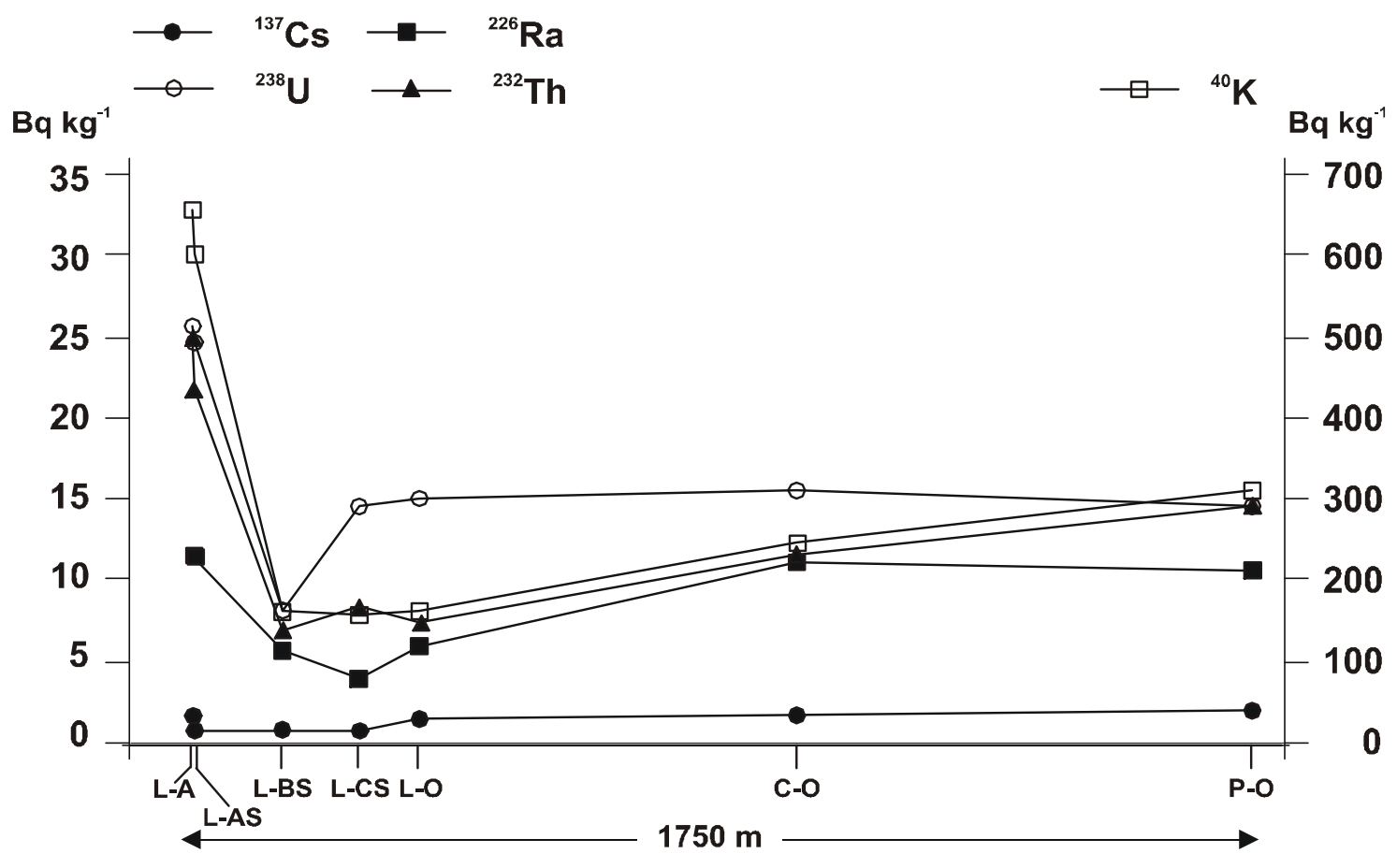



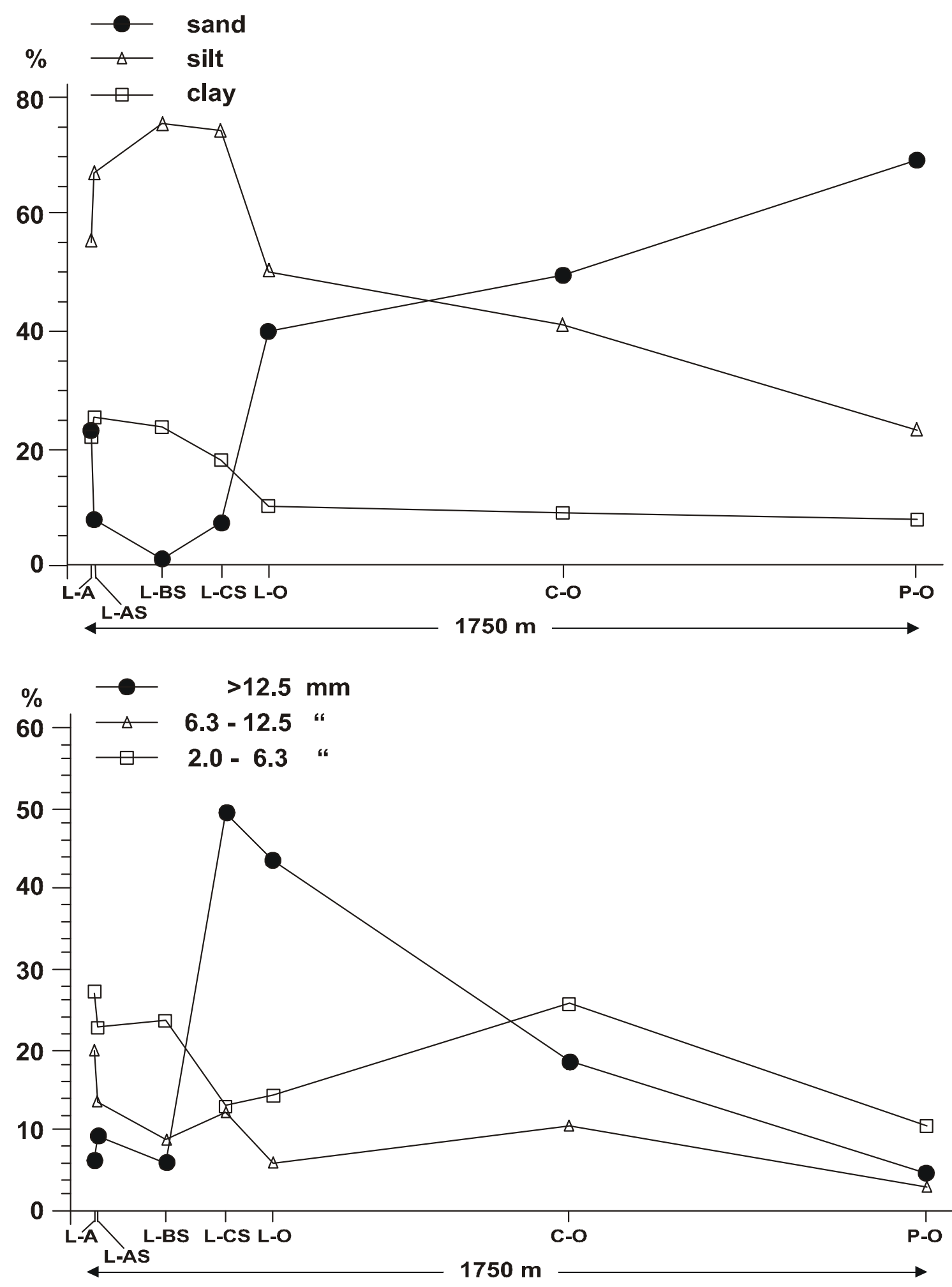

Fig. 3 


\section{L - CS}

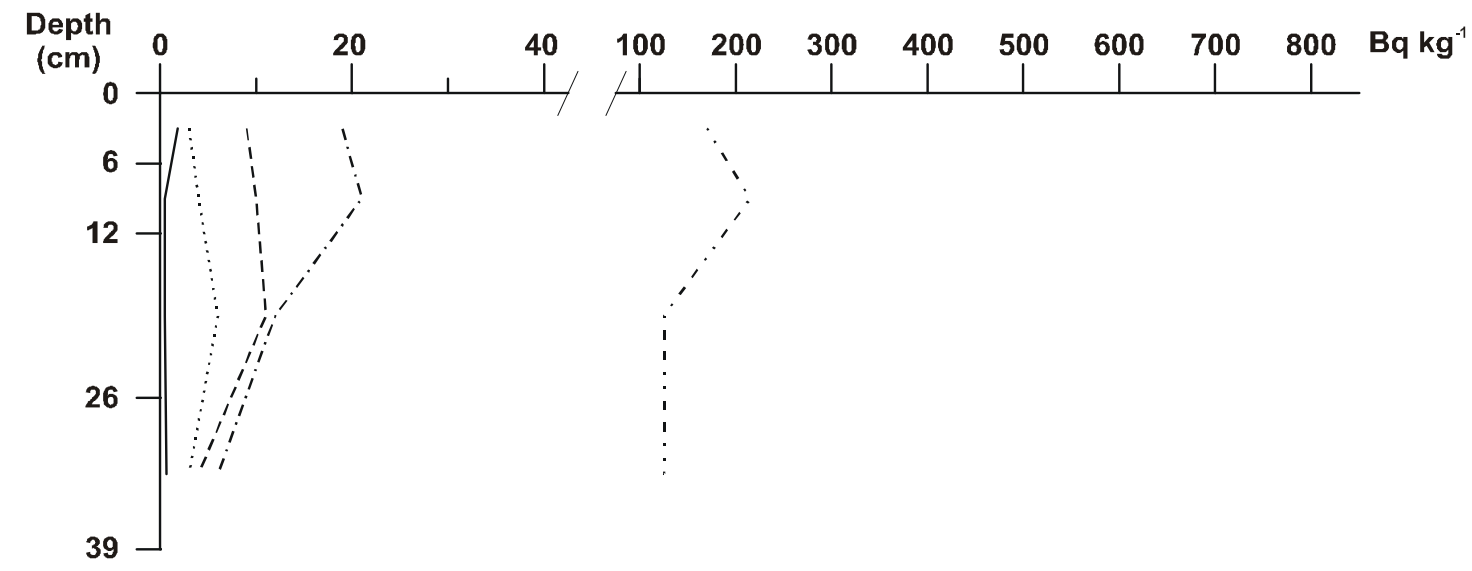

\section{L - BS}

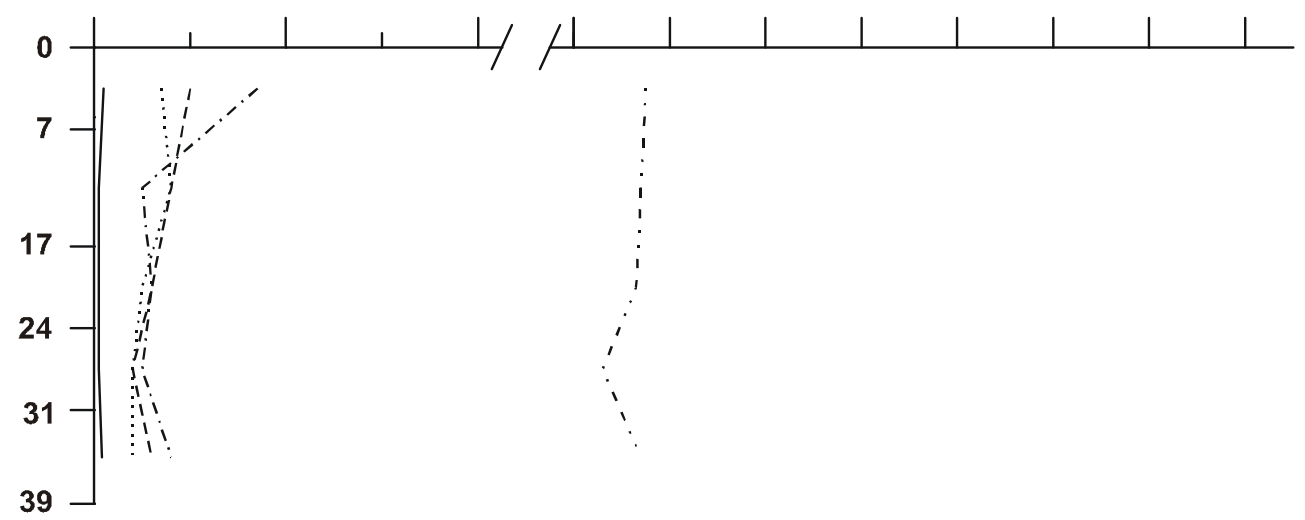

L - AS

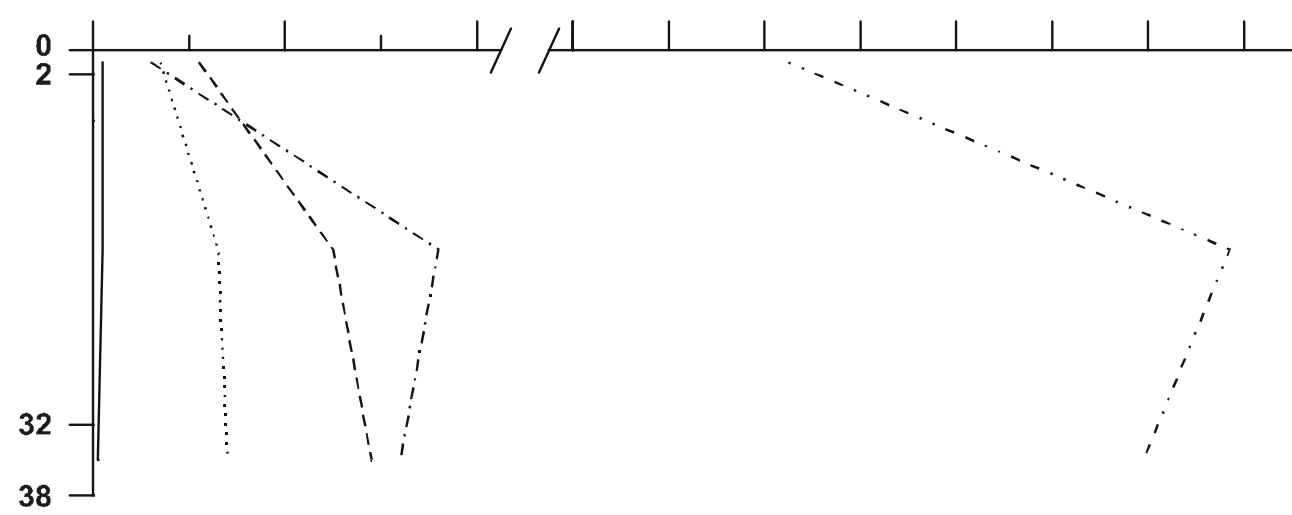

${ }^{137} \mathrm{Cs}$

${ }^{226} \mathrm{Ra}$

${ }^{232} \mathrm{Th}$

${ }^{238} U$

${ }^{40} \mathrm{~K}_{\mathrm{Bq} \mathrm{kg}}{ }^{-1}$

Fig. 4 
Fig. 5

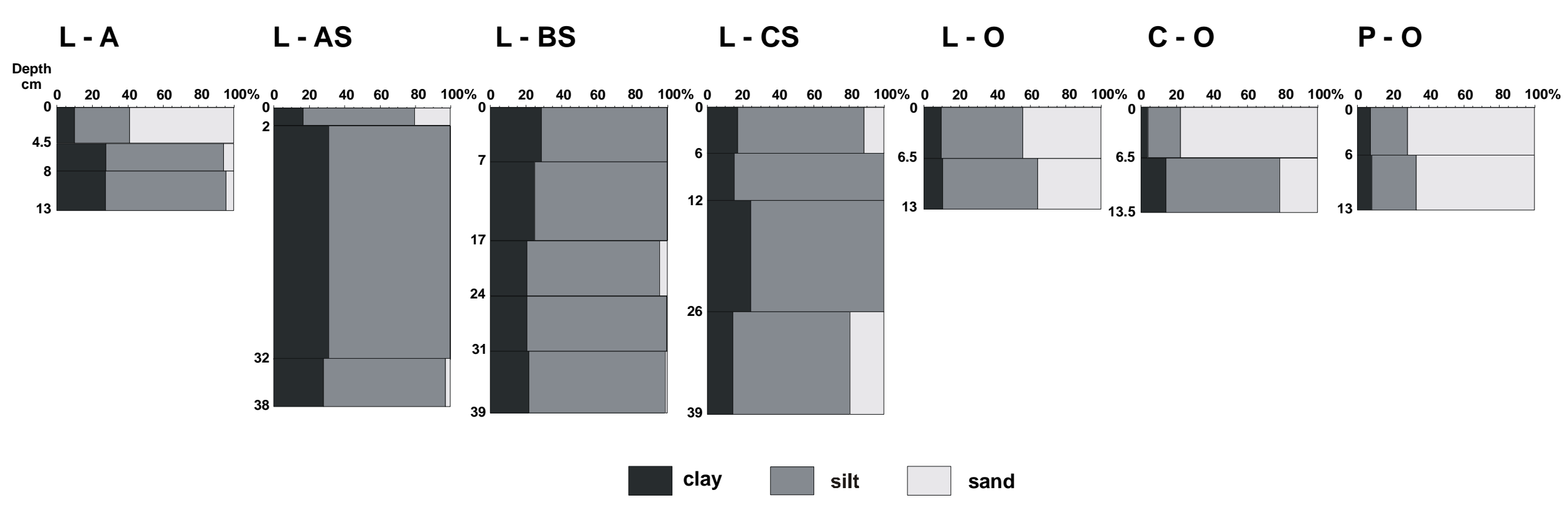

